\title{
Characterization of the Upper Cretaceous Sediments in the Ikpankwu-Ihube Axis, Okigwe, Southeastern Nigeria
}

\author{
Samuel Okechukwu Onyekuru* ${ }^{*}$, Chukwuma Julian Iwuagwu, Joy Okenyi, \\ Kelechi Denis Opara, Ukamaka Nwachiani Nwigbo \\ Department of Geology, Federal University of Technology, Owerri, Nigeria \\ Email: *onyekuru2001@yahoo.com, samuel.on yekuru@futo.edu.ng
}

How to cite this paper: Onyekuru, S.O., Iwuagwu, C.J., Okenyi, J., Opara, K.D. and Nwigbo, U.N. (2019) Characterization of the Upper Cretaceous Sediments in the Ikpankwu-Ihube Axis, Okigwe, Southeastern Nigeria. International Journal of Geosciences, 10, 724-744.

https://doi.org/10.4236/ijg.2019.106041

Received: March 19, 2019

Accepted: June 27, 2019

Published: June 30, 2019

Copyright $\odot 2019$ by author(s) and Scientific Research Publishing Inc. This work is licensed under the Creative Commons Attribution International License (CC BY 4.0).

http://creativecommons.org/licenses/by/4.0/

\begin{abstract}
Detailed characterization of the outcropping sediments in the Ikpankwu and Ihube axis was undertaken to validate lithostratigraphic boundaries and nomenclatures which had stirred up debates amongst scholars in recent times. Stochastic method established dominant facies associations and preferred stacking patterns, which were used to interpret environments of deposition (EODs), while foraminiferal and palynological analyses fingerprinted both paleo depths and age of the sediments. The results established the dominance of similar lithofacies at the basal parts of both sections indicating mappable geological units and members of the same lithostratigraphic unit. The basal lithofacies are succeeded up section, however, by different lithological units in both the KM 75 and Ikpankwu sections. Interpretations of EODs using lithofacies successions predicted fluvial to tidally-influenced shallow marine deposits, which are environments in close affinity with each other. Interpretations using abundance and diversity of micro fauna supported non-marine (coastal-deltaic) to middle neritic paleo-water depths also, typical of marginal to shallow marine EODs. Recovered foraminiferal assemblages in the shale samples from the upper parts of both sections, however, depicted deposits of Nsukka Formation despite variations observed in lithofacies assemblages because the identified Haplophragmoides species that populate the upper units had been used to define the Late Maastrichtian-Paleocene age. Sediments at the basal parts with mappable lithological units at both sections were rather populated by species that connote the Campanian-Maastrichtian age when the Mamu Formation sediments were deposited. Palynomorphs recovered from both the basal and upper sections also suggested Campanian-Maastrichtian and Late Maastrichtian-Paleocene age, indicative of Mamu and Nsukka Formation sediments, respectively.
\end{abstract}




\section{Keywords}

Assemblages, Biofacies, Characterization, Environment, Formation, Lithofacies

\section{Introduction}

The Anambra Basin is a structural depression located southwest of the Benue Trough and the immediate precursor to the Niger Delta. The basin is exposed over a roughly triangular territory, estimated at some $95,000 \mathrm{~km}^{2}[1]$ and separated from the Dahomey Basin by a Basement high-the Okitipupa Ridge and the Abakiliki Anticlinorium to the west and east, respectively. Its demarcation from the Bida Basin to the northwest is less clear and arbitrarily placed. The northeastern and southern boundaries of the basin bordering some parts of Benue Trough and the Niger Delta are still not very clear due to stacking of the basins [2]. There had, however, been strong tendencies in the past to merge the Anambra Basin with the Niger Delta Basin as one extensive coastal basin, or simply to consider one an extension of the other [3] [4]. The western, southwestern and southern boundaries of the Anambra Basin have however, been inferred to be around Adeigba, Umuezeanam-Nnewi and Akokwa areas respectively [5]; while its boundary in the northwestern region is placed to be around Ogurugu and in the southeastern side around Umulokpa community. In the northern part, the basin extended up to Orokam in Benue State.

The difficulties associated with the demarcation of Anambra Basin's geographic boundaries from other adjoining Nigerian coastal basins have been linked to the inability of researchers to clearly define the dispersal patterns of the Anambra basin's sedimentary fills [2]. It had been established that the basin consists of post-Santonian sediments, although adjudged to be thinly draped by pre-Santonian sediments [1] and capped by the Danian Sediments. Recent studies, however have also confirmed that pre-Santonian sediments are deposited and have been encountered in the basin [6]. If therefore, the spatial distributions of these deposits are established, it would be easy to demarcate the basin's geographic boundaries from its adjoining basins.

The spatial differentiation of some of the lithostratigraphic units in the Anambra Basin is somewhat difficult because of the identified stacking at basins' margins and arbitrary placement of formation boundaries (contacts) arising from widely spaced outcrop information, insufficient sub crop data and deficient seismic information, which are largely due to under exploration activities in the basin [7].

It is based on the foregoing that disagreements exist amongst scholars on boundaries and nomenclatures of some lithostratigraphic units (formations) in the Anambra Basin. The sections at Ikpankwu and KM 75, Ihube have not been spared of these disagreements as some scholars refer to the exposures as either 
Nsukka or Mamu Formation, or vice versa. This situation has distorted geologic maps and most lithostratigraphic correlations. It is in the light of these, therefore, that the characterization of sediments from the two sections using dominant environment(s) of deposition (EOD) and age was undertaken to ensure proper lithostratigraphic delimitation and nomenclature.

Several facies-based studies have been carried out in the area: The finite Markov Chain stochastic process had been utilized to predict the depositional environments of sediments by distilling lithofacies patterns in the outcrops of Mamu Formation exposed around the Okigwe-Uturu axis Anambra Basin SE Nigeria [8]. The successions in the study area were masked severely by several erosion truncations and road construction activities. The study revealed transition patterns that are Markovian, indicating historical links between the successive lithofacies and consequently their environments of deposition. The environment of deposition ranged from open marine through lower delta front (distal bar) to near-shore environment with occasional fluvial influence.

In the sedimentary facies analysis of the Bima Sandstone in Gombe area using a combination of grain size data, primary sediments structures and stratification patterns, the sediments of the exposed sections were interpreted as coarse grained sands of the braided river deposit [9]. Similarly, the use of Markov chain stochastic process in the analysis of the vertical lithofacies of the Bida Sandstone interpreted the sediments as products of braided river depositional system with well-developed flood plains and lakes behind non-cohesive river banks [10]. They noted that the cycle indicated channel migrations within broad topographic variable alluvial plains fed by basin margin fans.

An integrated sedimentological, macrofossil, trace fossil, and palynofacies studies of Paleocene-Middle Eocene outcrops in the Syncline complex of southeastern Nigeria around Umuahia area described four lithofacies associations (I-IV) and five depositional sequences comprising Nsukka Formation, Lower Imo Formation, Upper Imo Formation, Ameki Formation and Ogwashi-Asaba Formation [11]. The study noted that each sequence is bounded by a type-1 sequence boundary, and contains basal fluvio-marine sediments representing the transgressive systems tract, which are succeeded by shore face and foreshore strata of the high-stand systems tract. From the study, the occurrence of the estuarine cycles in the Paleogene successions is interpreted as evidence of significant relative sea level fluctuations, and the presence of type-1 sequence boundaries were linked to stratigraphic signatures of major drops in relative sea level during Paleocene and Eocene times.

\section{Materials and Methods}

\subsection{The Study Area}

The study area is located between Latitudes $5^{\circ} 40^{\prime}$ and $6^{\circ} 50^{\prime} \mathrm{N}$ and Longitudes $6^{\circ} 50^{\prime}$ and $7^{\circ} 50^{\prime} \mathrm{E}$ (Figure 1), which encloses a major part of Ihube community in SE Nigeria. The Ikpankwu section is a quarry site for sand aggregates while the 


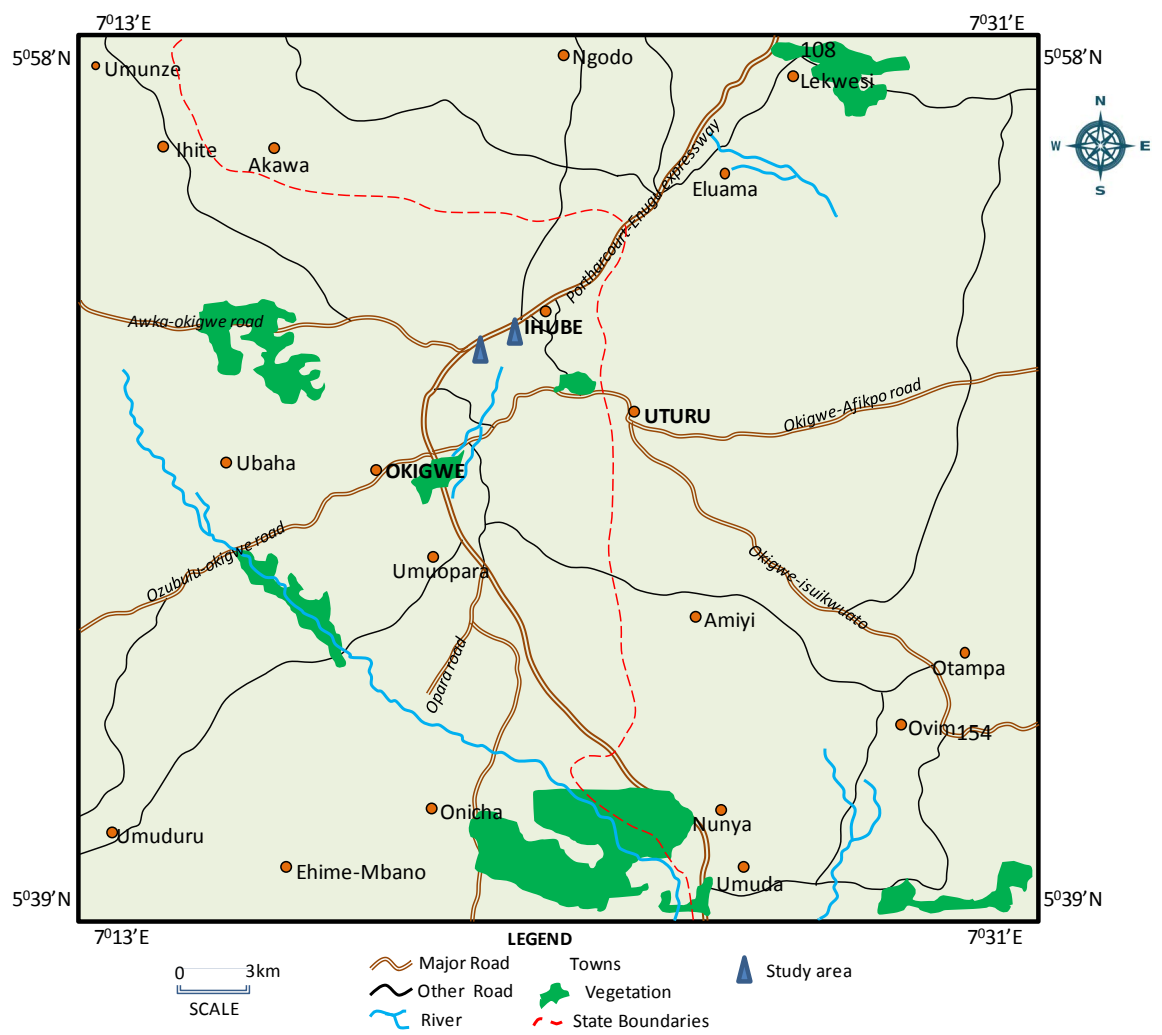

Figure 1. Location and accessibility map, showing sparse vegetation and the Ikpankwu and Ihube sections at the central parts of the study area [16].

KM 75 Section was created by the road traversing the Port Harcourt-Enugu express way. The area was chosen for this study because it is very accessible and the road trending NE-SW, i.e. strike of the deposits in the area ensured the exposure of many lithostratigraphic units deposited in the southern Anambra Ba$\sin$.

The tectonic and geologic history of Nigerian sedimentary basins including the Anambra Basin followed the break-up of the South American and African continents in the Early Cretaceous [12] [13]. The stratigraphic history of the region has been well documented [12] [14] [15]. The Late Cretaceous stratigraphic succession in the basin began with Campanian-Maastrichtian Nkporo Shale and its lateral equivalent: the Enugu Shale and Owelli Sandstone. These basal units are overlain successively by the Early-Middle Maastrichtian Mamu Formation (Lower Coal Measures), the Middle Maastrichtian Ajali Sandstone and the Nsukka Formation (Upper Coal Measures) which extends from the Late Maastrichtian into the Danian. The Tertiary succession consists of the Palaeocene Imo Shale. These lithostratigraphic units are spatially distributed in the study area (Figure 2).

\subsection{Lithofacies Analysis}

The strategy adopted in the study involved the extraction of characteristic lithological and other physical motifs extracted from the 2 stratigraphic sections. The 


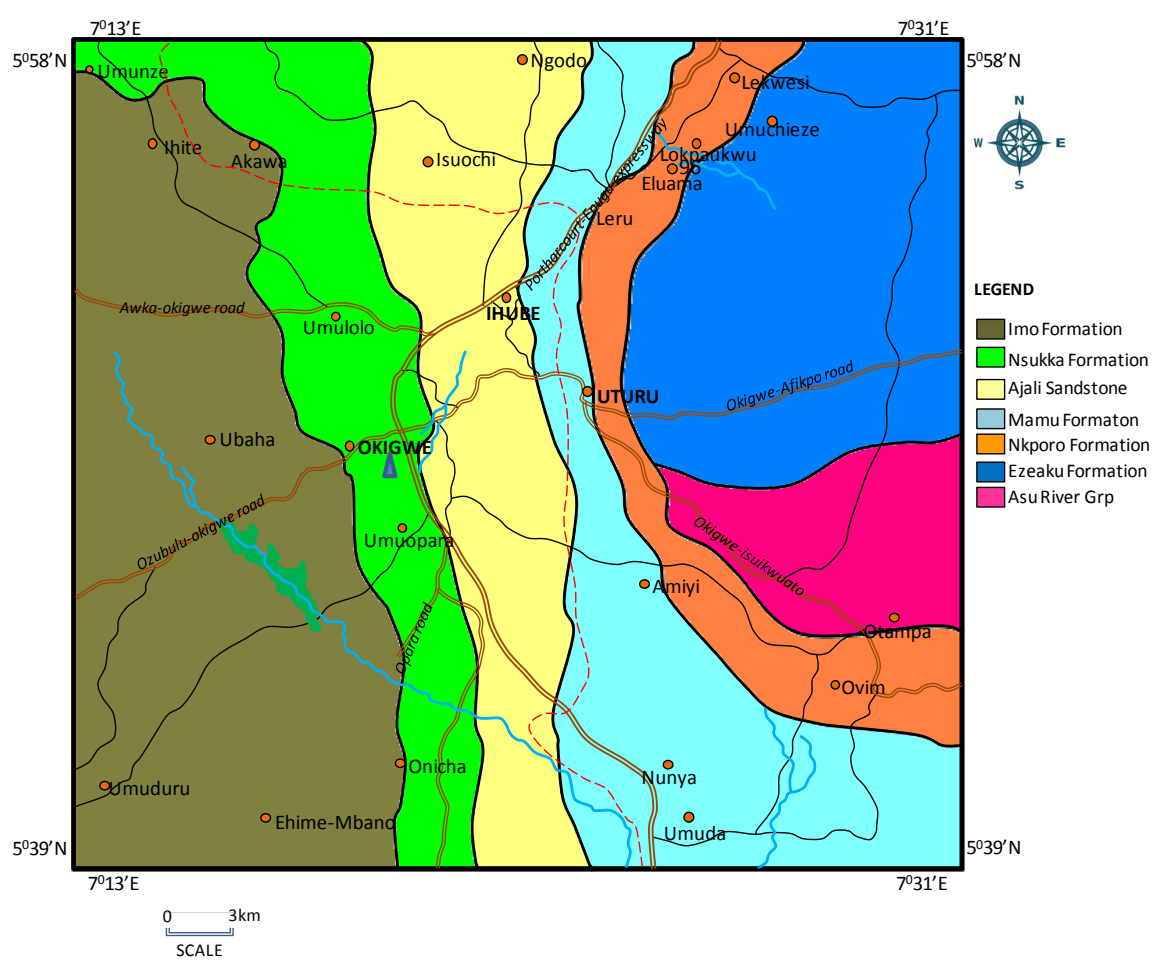

Figure 2. Geological map of the study area showing the spatial distribution of the lithostratigraphic units (Modified after [16]).

lithofacies and local facies summaries were interpreted by considering possible depositional processes that might have given rise to the features as indicated by the observed inherent primary sedimentary structures, textures and stacking patterns in the units. The Embedded Markov Matrix was thereafter utilized to establish facies relationships [17] [18].

The Embedded Markov Matrices utilized in the study involved 1) Erection of transition count matrix for each section 2) Tabulation of transition probability matrix 3) Tabulation of independent trial probability matrix and 4) Erection of difference matrix,

The three matrices (observed transition probability, random probability and difference probability) were calculated from transition count matrix using the following formulae:

$$
P_{i j}=F_{i j} / R_{t},
$$

where $P_{i j}$ is observed transition probability of $i$ being followed by $j F_{i j}$ is the number of transitions of $i$ to $j ; R_{t}$ is the row total [15].

$$
R_{i j}=n_{j} / N-n_{i},
$$

where $r_{i j}$ is the random probability of transition from facies $i$ to facies $j, n_{i}$ and $n_{j}$ are the number of occurrences of facies $i$ and $j$ respectively; and $N$ is the total number of occurrences of all facies [18].

$$
D_{i j}=P_{i j}-r_{i j} \text {, }
$$


where $d_{i j}$ is the difference between the observed probability $\left(P_{i j}\right)$ and the random probability $\left(r_{i j}\right)[18][19]$.

At the end of the analysis, a composite facies relationships diagram (local summary) was established using the result of the difference matrix, which gave a better understanding of the structure of the raw data and facies relationship diagrams that were used as basis for overall interpretation of facies in terms of depositional environment. Interpretations using established facies affinities/associations and the comparison of obtained local summaries with established facies models also helped in the interpretation of EODs of the studied units.

\subsection{Foraminiferal Analysis}

Five samples were selected for micro faunal analysis. The preparation and analysis of each of the samples were carried out using the procedures outlined in [20]. The absolute ages of the units were also obtained via correlation to [20].

$100 \mathrm{~g}$ of each sample was broken into chips and placed in an aluminum bowl containing two (2) teaspoonful of anhydrous sodium carbonate and sufficient quantity of $10 \%$ concentrated hydrogen peroxide. The mixture was then heated on a hot plate until the sample was completely smeared on boiling and then put off and allowed to cool. The sample was washed under a gently running tap through a set of three (30-, 60- and 200- $\mu$ ) sieve meshes. Residues from each fraction were dried in an oven at about $80^{\circ} \mathrm{C}$. The dried samples were individually studied under Zeiss binocular stereomicroscope for micro faunas such as foraminifera and ostracods.

\subsection{Palynological Analysis}

The selected five shale samples for floral analysis, were analysed using the procedures expounded in [21]. Hydrochloric acid, $36 \%$ in concentration was added to the selected sample until effervescence stopped. This ensured the removal of all carbonates. Then $40 \mathrm{ml}$ of HCL was added and heated to remove the silica fluoride gel; Methanol was then added to separate the sample debris. Five to seven drops of Nitric acid was added to oxidize the residue, which cleaned the palynomorphs and removed the lignin. Potassium hydroxide was thereafter added to neutralize any acid present. Two to three drops of Safranin O was added before sieving, then centrifuging was done to the solution. A small quantity of the residue was then pipetted out, dried and placed on the slide for microscopic identification.

\section{Results}

\subsection{Lithostratigraphic Study}

The result of units that were later grouped into lithofacies types delineated in this study are briefly summarised in the subsections below, while the lithologs and detailed descriptions of each of the units are shown in Figure 3 and Figure 4. Representative outcrop sections and some identified facies are shown in Figure 5. 


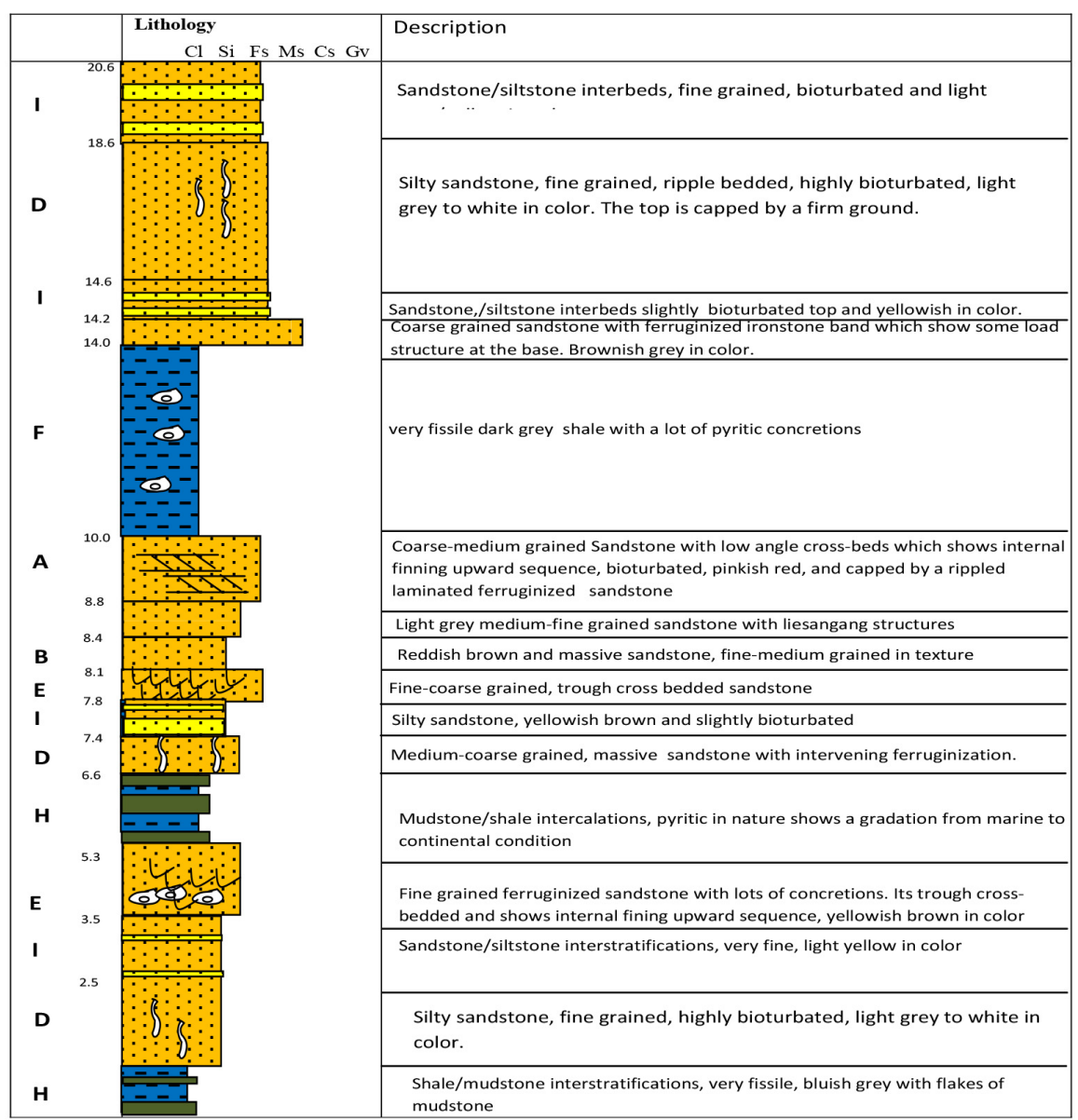

Figure 3. Litholog of Section at Km 75 Enugu-Port Harcourt Road, Ihube showing the different facies (A)-(I), sedimentary structures, texture and vertical extent of the exposure.

\section{Planar cross bedded sandstone facies A}

Facies A was identified in the two locations studied. It is comprised of medium to coarse grained, poorly to moderately sorted sandstone with low to medium angle cross beds, whose fore sets are draped with mud (Figure 5(d)). It has sharp contacts with the overlying mudstone facies. The thickness of the facies is about $2 \mathrm{~m}$. The planar cross bedded sandstone facies is (A) is ferruginized at the top in both locations.

\section{Massive sandstone facies B}

This facies is white to pink in color, moderately to poorly sorted, fine to medium grained Sandstone. The absence of any observable sedimentary structure may be the result of continuous high energy of deposition or its structure may have been destroyed by massive bioturbation.

\section{Mudstone facies C}

This facies was delineated only at the Ikpankwu quarry location. It is light grey in color, slightly bioturbated with an average thickness of about $2 \mathrm{~m}$.

\section{Bioturbated Sandstone facies D}

This facies is ubiquitous in both locations. It showed imprints of trace fossils especially, burrows belonging to Skolithos ichnogenera. The lithofacies is often 


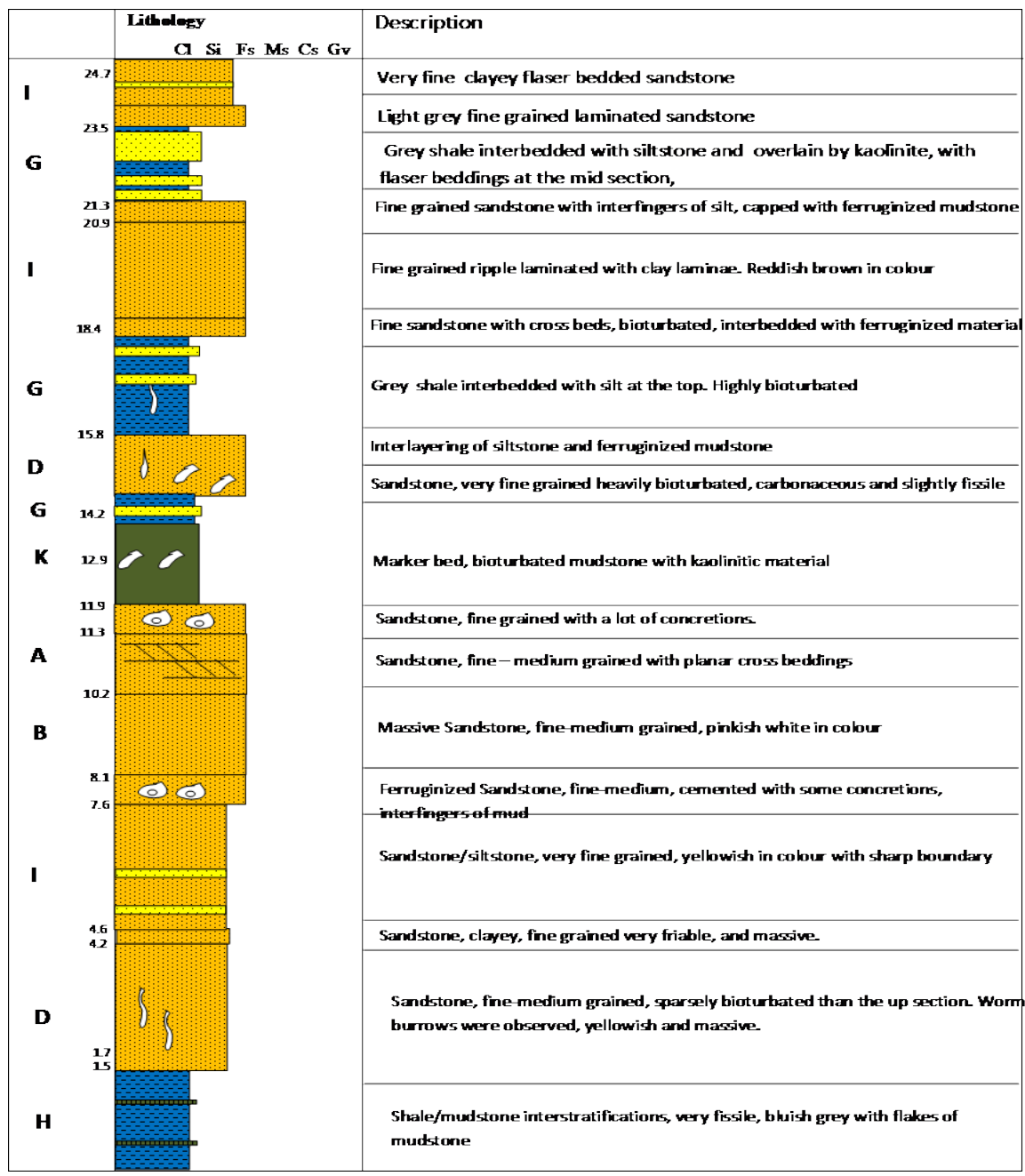

Figure 4. Litholog of the section at Ikpankwu Quarry, off Ihube junction also showing the different facies (A) - (I), sedimentary structures, texture and vertical extent of the exposure.

ripple bedded and ferruginized. Texture is fine to medium grained with an average thickness of $2.5 \mathrm{~m}$.

\section{Trough cross bedded sandstone facies $\mathrm{E}$}

This facies was observed only at the Km 75 section and displayed fore sets that are curved and abruptly terminate tangentially with the lower bedding surface. The texture of the facies is fine to medium grained sandstone. This facies has been associated with dune migration.

\section{Dark grey laminated shale facies $\mathrm{F}$}

This facies was also observed at the $\mathrm{km} 75$ section. It is comprised of dark grey and fissile shale with lots of pyritic concretions. Weathered exposures easily give off yellowish colouration due to the iron content (Figure 5(a)).

\section{Shale/Siltstone facies $\mathrm{G}$}

This facies was observed at the Ikpankwu quarry site. It is comprised of shale/siltstone interbeds with flaser bedded characteristics. It is often bioturbated. 

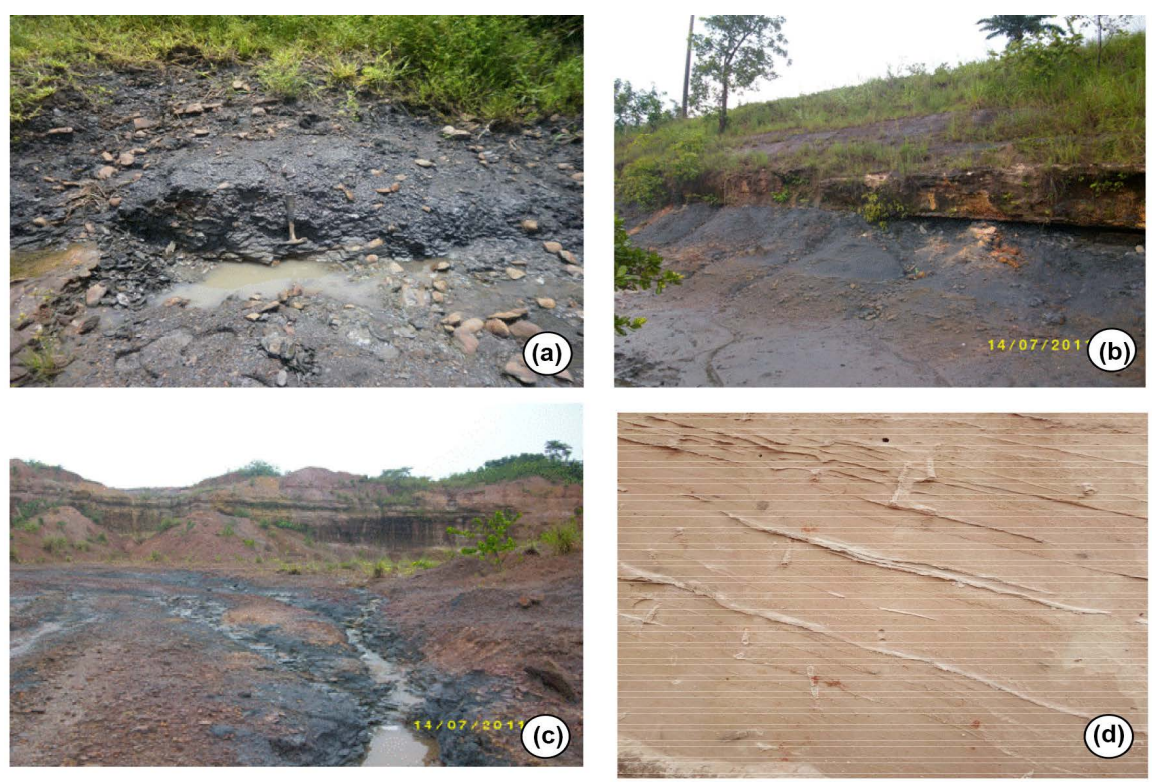

Figure 5. (a) = Dark-grey, Pyritic and laminated shale at $\mathrm{Km} 75$ Enugu-Port Harcourt road $(b)=$ Silty Sandstone capping the section at Km 75, Enugu-Port Harcourt road (c) = The outcrop section at Ikpankwu showing underlying dark grey pyritic Shale $(\mathrm{d})=$ Cross bedded sandstone facies at Ikpankwu.

\section{Shale/Mudstone facies $\mathrm{H}$}

This facies showed interbeds of shale and mudstone units with the thickness of the mudstone unit increasing up section indicating a shoaling up. The lower shale units are pyritic (Figure $5(\mathrm{c})$ ).

\section{Horizontally bedded Sandstone facies I}

This facies consists of beds of fine grained sandstone that alternate with siltstone (Figure $5(\mathrm{~b})$ ). The facies is fine to medium grained often ripple bedded with an average thickness of $2 \mathrm{~m}$.

\subsection{Result of Lithofacies Studies}

Figure 6 and Figure 7 show the facies relationship diagrams (FRDs) of the two lithosections in KM 75 and Ikpankwu, respectively. The FRDs were erected based on observed facies transitions in the two sections (Figure 3 and Figure 4). Tables 1-8 on the other hand show the computed transition count matrix, observed transition probabilities, transition probabilities and difference matrix for the two lithosections of the study area.

The composite facies relationship diagrams (Figure 8 and Figure 9) for the respective sections constructed using the difference matrix (Table 4 and Table 8) gave a better understanding of the structure of the raw data and finally, a facies relationship diagram that can be used as a basis for overall interpretation of facies in terms of depositional environment, was realised.

\subsection{Result of Foraminiferal Analysis}

The result of foraminiferal analysis revealed that the study area is rich in benthonic forams, but devoid of planktonic Forams (Figure 10). Age interpretation 


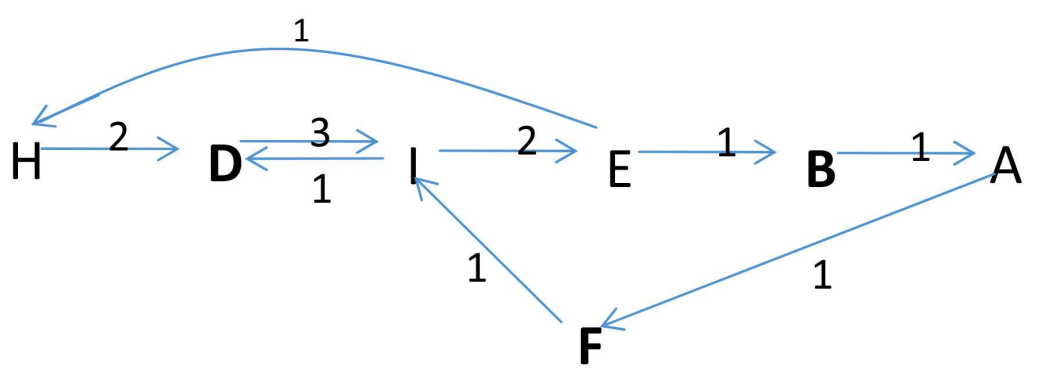

Figure 6. FRD for section at Km 75 Enugu-Port Harcourt road, Ihube.

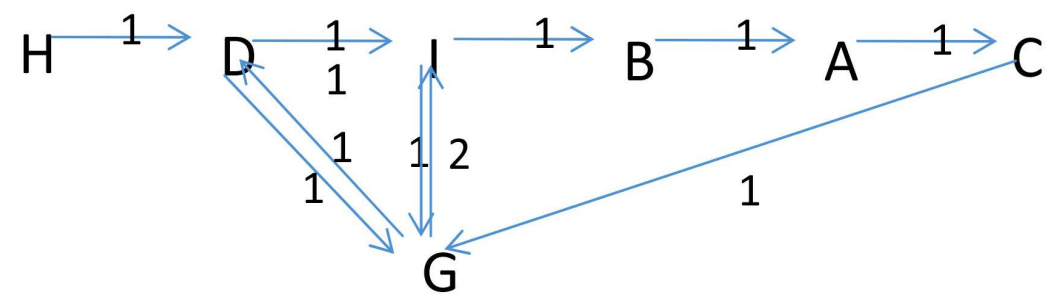

Figure 7. FRD for section at Ikpankwu quarry, off Ihube junction.

Table 1. Observed Transition count matrix of the section at Km 75, Enugu-Port Harcourt road, Ihube

\begin{tabular}{|c|c|c|c|c|c|c|c|c|}
\hline & A & B & $\mathrm{D}$ & E & $\mathrm{F}$ & $\mathrm{H}$ & I & $\mathrm{Rt}$ \\
\hline A & & & & & 1 & & & 1 \\
\hline B & 1 & & & & & & & 1 \\
\hline $\mathrm{D}$ & & & & & & & 3 & 3 \\
\hline E & & 1 & & & & 1 & & 2 \\
\hline $\mathrm{F}$ & & & & & & & 1 & 1 \\
\hline $\mathrm{H}$ & & & 2 & & & & & 2 \\
\hline I & & & 1 & 2 & & & & 3 \\
\hline $\mathrm{Ct}$ & 1 & 1 & 3 & 2 & 1 & 1 & 4 & 13 \\
\hline
\end{tabular}

$\mathrm{Rt}=$ Row Total, $\mathrm{Ct}=$ Column Total, $\mathrm{A}-\mathrm{I}=$ Facies.

Table 2. Observed transition probabilities for section at $\mathrm{Km} 75$ Enugu-Port Harcourt road, Ihube.

\begin{tabular}{|c|c|c|c|c|c|c|c|}
\hline & A & B & $\mathrm{D}$ & E & F & $\mathrm{H}$ & I \\
\hline A & & & & & 1.00 & & \\
\hline B & 1.00 & & & & & & \\
\hline D & & & & & & & 3.00 \\
\hline E & & 0.5 & & & & 0.5 & \\
\hline $\mathrm{F}$ & & & & & & & 1.00 \\
\hline $\mathrm{H}$ & & & 1.00 & & & & \\
\hline I & & & 0.33 & 0.66 & & & \\
\hline
\end{tabular}


Table 3. Transition probabilities for random sequence for section at $\mathrm{Km} 75$ Enugu-Port Harcourt road, Ihube.

\begin{tabular}{cccccccc}
\hline & A & B & D & E & F & H & I \\
\hline A & & & & & 0.07 & & \\
B & 0.07 & & & & & & \\
D & & & & & & & \\
E & & 0.08 & & & & & \\
F & & & & & & & \\
H & & 0.25 & & & \\
I & & 0.25 & 0.20 & & & \\
\hline
\end{tabular}

Table 4. Difference matrix for section at Km 75 Enugu-Port Harcourt road, Ihube.

\begin{tabular}{cccccccc}
\hline & $\mathrm{A}$ & $\mathrm{B}$ & $\mathrm{D}$ & $\mathrm{E}$ & $\mathrm{F}$ & $\mathrm{H}$ & $\mathrm{I}$ \\
$\mathrm{A}$ & & & & & +0.92 & & \\
$\mathrm{~B}$ & +0.92 & & & & & & \\
$\mathrm{D}$ & & & & & & & +2.64 \\
$\mathrm{E}$ & & +0.42 & & & & & +0.34 \\
F & & & & & \\
H & & +0.75 & & & \\
$\mathrm{I}$ & & +0.08 & +0.46 & & &
\end{tabular}

Table 5. Observed Transition Count Matrix of the Ikpankwu quarry section.

\begin{tabular}{|c|c|c|c|c|c|c|c|}
\hline & A & B & C & $\mathrm{D}$ & G & I & $\mathrm{Rt}$ \\
\hline $\mathrm{A}$ & & & 1 & & & & 1 \\
\hline B & 1 & & & & & & 1 \\
\hline $\mathrm{C}$ & & & & & 1 & & 1 \\
\hline $\mathrm{D}$ & & & & & 1 & 1 & 1 \\
\hline G & & & & 1 & & 2 & 2 \\
\hline $\mathrm{H}$ & & & & 1 & & & 3 \\
\hline I & & 1 & & & 1 & & 2 \\
\hline $\mathrm{Ct}$ & 1 & 1 & 1 & 2 & 3 & 3 & 11 \\
\hline
\end{tabular}

was therefore based on the arenaceous assemblages identified in the analyzed samples. The identified forms include: Ammobaculites coprolithiformis, Haplophragmoides sahariense, Ammobaculites amabensis, Haplophragmoides talokaense, Trochamina dutsuna and Anomalinoides midwayaensis and Ammobaculites texanus (Figure 11). Detailed foraminiferal micropaleontological analysis was achieved by correlating the identified forms with stratigraphically important Cretaceous arenaceous Benthic Foraminifera of the study area propounded by [22]. 
Table 6. Observed transition probabilities for Ikpankwu quarry section.

\begin{tabular}{ccccccc}
\hline & $\mathrm{A}$ & $\mathrm{B}$ & $\mathrm{C}$ & $\mathrm{D}$ & $\mathrm{G}$ & $\mathrm{I}$ \\
\hline $\mathrm{A}$ & & & & & \\
$\mathrm{B}$ & 1.00 & & & & & \\
$\mathrm{C}$ & & & & 1.00 & \\
$\mathrm{D}$ & & & & 0.5 & 0.5 \\
$\mathrm{G}$ & & & 0.33 & & 0.60 \\
$\mathrm{H}$ & & & & & \\
$\mathrm{I}$ & & & & & & \\
\hline
\end{tabular}

Table 7. Transition probabilities of random sequences for Ikpankwu quarry section.

\begin{tabular}{|c|c|c|c|c|c|c|}
\hline & A & B & $\mathrm{C}$ & $\mathrm{D}$ & G & I \\
\hline A & & & 0.09 & & & \\
\hline B & 0.09 & & & & & \\
\hline C & & & & & 0.29 & \\
\hline $\mathrm{D}$ & & & & & 0.3 & 0.3 \\
\hline G & & & & 0.22 & & 0.33 \\
\hline $\mathrm{H}$ & & & & 0.18 & & \\
\hline I & & 0.11 & & & 0.33 & \\
\hline
\end{tabular}

Table 8. Difference Matrix for Ikpankwu quarry section.

\begin{tabular}{|c|c|c|c|c|c|c|}
\hline & A & B & $\mathrm{C}$ & $\mathrm{D}$ & G & I \\
\hline A & & & +0.91 & & & \\
\hline B & +0.91 & & & & & \\
\hline C & & & & & +0.71 & \\
\hline D & & & & & +0.2 & +0.2 \\
\hline G & & & & +0.11 & & \\
\hline $\mathrm{H}$ & & & & +0.82 & & \\
\hline I & & +0.39 & & & +0.17 & \\
\hline
\end{tabular}

\subsection{Result of Palynological Analysis}

Various types of dispersed organic matter and palynomorph groups were identified (Figures 11-13) based on systematics described by several authors [23] [24] [25] [26]. Identified palynomorphs included spores and pollen, fungal remains, freshwater algae, marine palynomorphs (dinoflagellates, acritarchs, micro foraminiferal inner linings), structured phytoclasts (wood, cuticles, parenchyma), unstructured phytoclasts (resins, comminuted and degraded fragments), black debris, and amorphous organic matter following the template of [11]. 


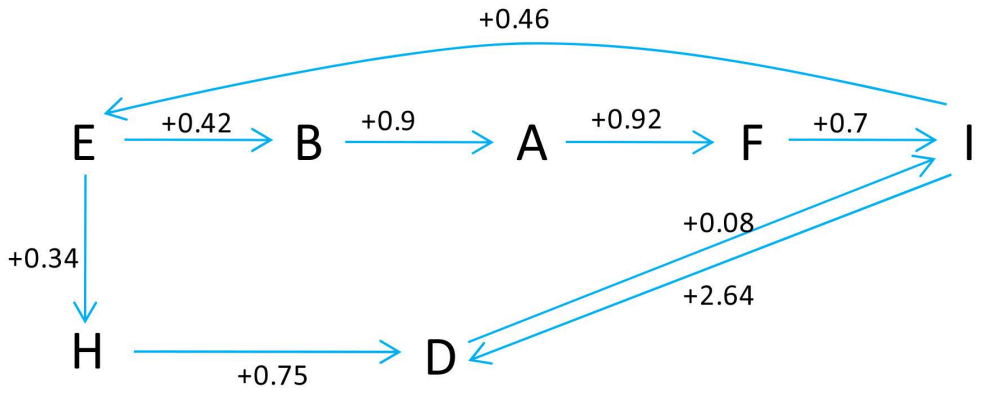

Figure 8. Composite FRD for Mamu Formation at Km 75 Enugu-Port Harcourt road, Ihube.

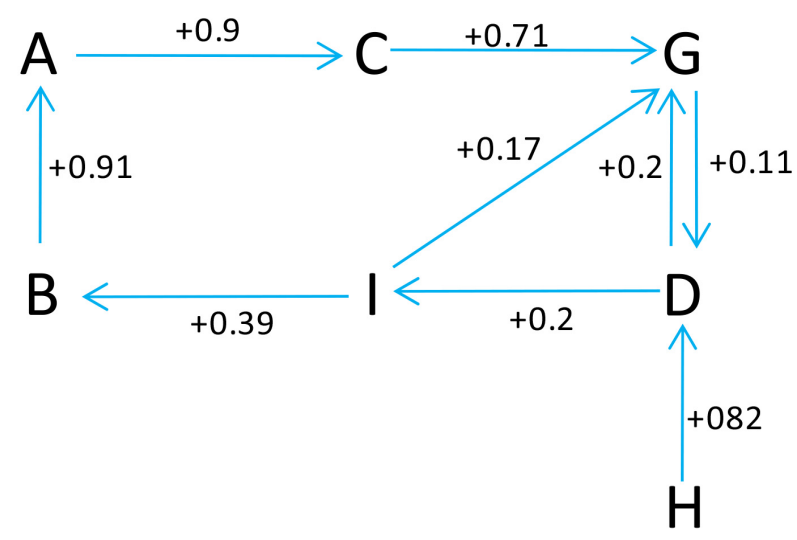

Figure 9. Composite FRD for the section at Ikpankwu Quarry.

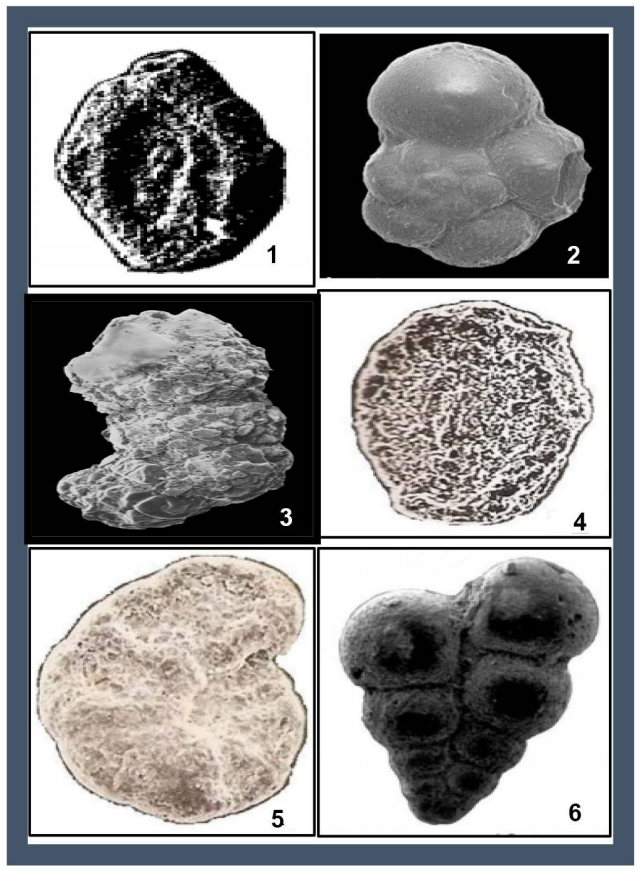

Figure 10. Sketch diagram of identified Forams 1) H. talokaense, 2) Hedbergella holmdelensis, 3) Ammobaculites coprolithiformis, 4) Ammobaculites amabensis; 5) H. sahariense; 6) Heterohelix globulosa. 


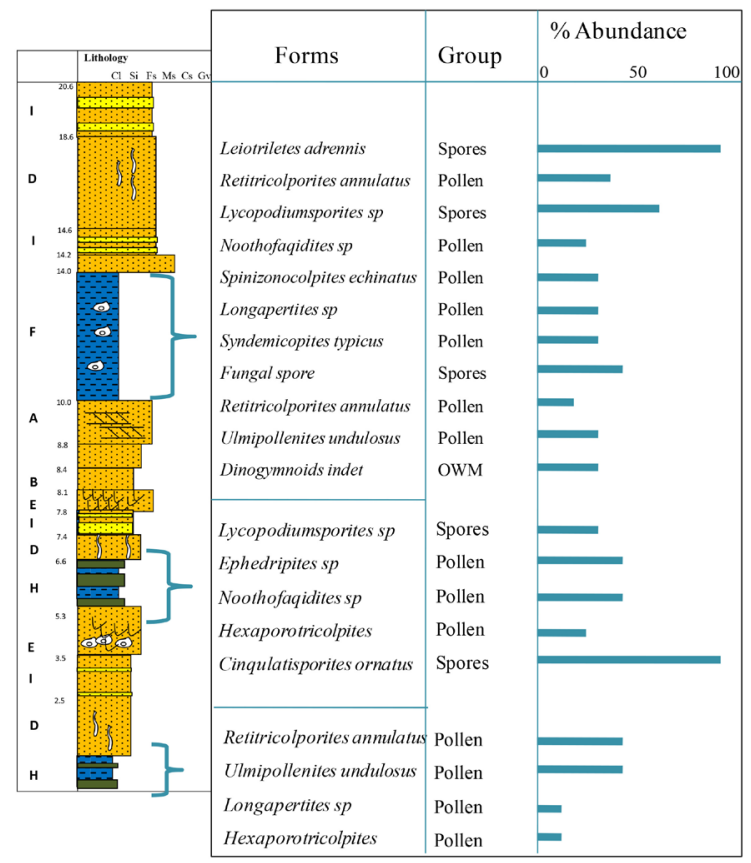

Figure 11. Distribution chart of palynomorphs from the section at $\mathrm{Km} \mathrm{75}$, Enugu-Port Harcourt road, Ihube.

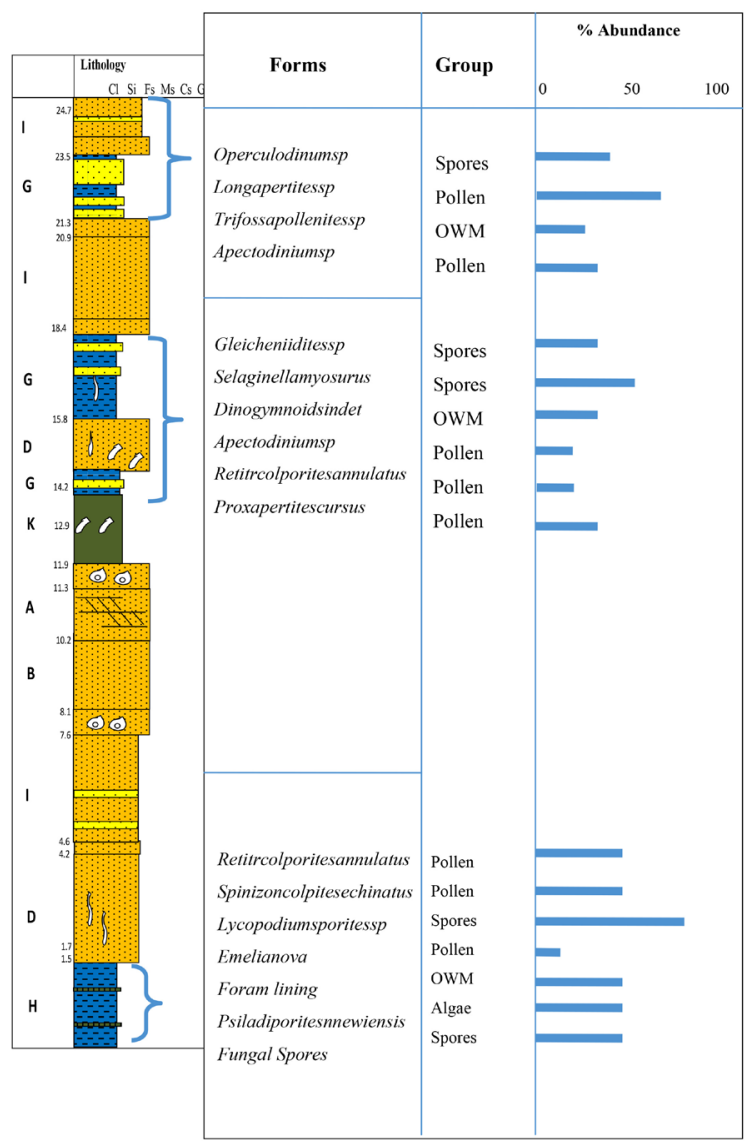

Figure 12. Distribution chart of palynomorphs from the Ikpankwu quarry section, Ihube. 

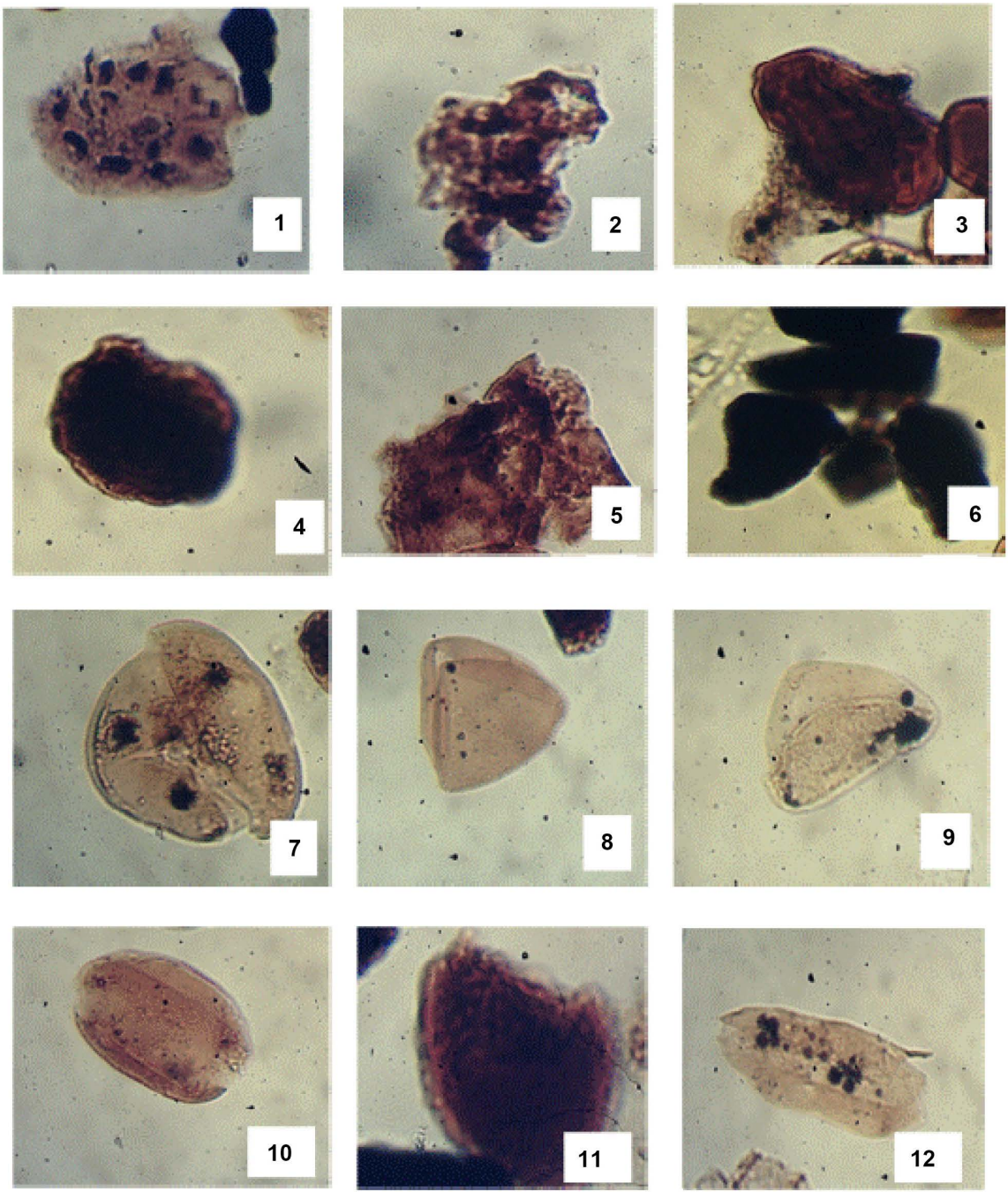

Figure 13. Representative photomicrographs of some palynomorphs identified in the study area. 1. Pitted wood 2. Degraded wood 3. Araidnaesporites spinosus 4,11,5. Amorphous organic matter 6. Black debris 7. Psiltricolpites sp. 8, 9. Longapertites sp. 10, 12. Retidisporites sp.

\section{Discussion}

\subsection{Interpretation of Environment of Deposition (EOD) Using Lithofacies Analysis}

Lithofacies interpretation forms the primary tool for identifying the depositional conditions under which the sediments were deposited and preserved.

Various lithofacies can be grouped as architectural elements, which are characterized by distinctive facies assemblages, internal geometry, external form and vertical profile [27] [28]. The recognition of these architectural elements, their inherent characteristics and relationships, aided the interpretation of the local and regional processes of deposition in the study area. The lithofacies types identified in the study included:

Cross-bedded sandstone facies (A), Massive sandstone facies (B), Mudstone facies (C), Bioturbated sandstone facies (D), Trough cross-bedded sandstone fa- 
cies (E), Laminated calcareous shale facies (F), Shale and siltstone facies (G), Shale and mudstone facies $(\mathrm{H})$, Very fine laminated sandstone and siltstone facies (I).

Sediments in lithofacies A and D are cross bedded and heavily bioturbated with Ophiomorpha burrows. The presence of these structures indicates tidal processes with high energy [29] [30] [31]. However, the presence of lateral accretion surface within the studied sandstone sediments suggests fluvial action [28] [29] [30]. These field observations showed that the studied sediments were deposited under tidal and fluvial channels' interaction as usually seen in littoral environments. The planar cross bedded sandstone facies is interpreted as traction current deposits. Medium-scale planar cross bedding resulted from the preservation of straight crested dunes and sand waves and transverse bars [31] [32]. Whereas strongly bioturbated sandstones with abundant Skolithos and Ophiomorpha traces probably represented the upper shoreface and foreshore environments of deposition (EOD) [33] [34] [35] [36].

The massive sandstone facies (B) is interpreted as a water-laid deposit. Most longitudinal bars are stable bedforms at flood stage, when all the bed loads are in motion. The absence of horizontal lamination or cross lamination typically formed by traction could be due to influence of grain flow depositional process [27]. The mudstone facies (C) comprises light grey and brown mudstone. It is sandy and carbonaceous with commuted plant remains. This facies is in all probability a suspension deposit. The characteristic minute grains and good sorting favour transportation in, and deposition from suspension [9] [37].

Alternating thin units of fine laminated sandstones and siltstones of lithofacies (I) suggests rhythmic sedimentation [38] and the fact that these alternating units have wave ripple laminations, lenticular and flaser bedding, indicates that there were frequent fluctuations in current strength. Such conditions are common in sub tidal and intertidal settings [39].

The Trough cross-bedded sandstone facies (E) is interpreted as a unidirectional traction current deposit [40] [41]. The presence of carbonaceous materials and fissile structure of the laminated shale facies (F) as observed from the field data suggests deposition in shelf to shoreface environment [42] [43].

\subsection{Interpretation using Facies Assemblages and Successions}

The composite facies relationship diagrams constructed for the respective formations was used as a basis for interpretation of facies in terms of environment of deposition (EOD). The FRDs showed the dominance of facies (H, D, I) assemblage. It also showed the restriction of this facies assemblage to the basal portion of both stratigraphic sections. The stratigraphic succession in $\mathrm{Km} 75$, Ihube showed that the shale-mudstone facies $(\mathrm{H})$ is usually overlain by the bioturbated sandstone facies (D), laminated sandstone-siltstone facies (I) then Trough cross-bedded sandstone facies (E) except in the up section where the assemblage was succeeded by massive sandstone facies, cross bedded sandstone fa- 
cies and laminated black shale. In the Ikpankwu quarry section, the basal portion is also characterized by the $\mathrm{H}, \mathrm{D}, \mathrm{I}$ assemblage whereas in the up section, it is replaced by the $G$ and I assemblages comprising of Shale-siltstone facies and fine laminated sandstone siltstone facies. These affinities did not only signify similar depositional processes but also established similar and spatially correlatable lithostratigraphic units (formations) in the study area. In other words, lithofacies assemblage affinities established that the basal and upper lithostratigraphic units in both sections were the Mamu and Nsukka Formations, respectively.

\subsection{Interpretation using Foraminifera Assemblages}

The result of foraminiferal analysis reveals that the study area is rich in benthonic forams, but devoid of planktics. The absence of planktonic foraminifera in the samples, attest and confirm shallow and probably harsh ecological factors [32]. Biostratigraphic data of studied shale samples showed that the Nsukka Formation at Km 75 Enugu-Port Harcourt, Ihube and the upper parts of the section at Ikpankwu were dominated by Haplophragmoides species including ( $H$. Hausa and H. Sahaliense) Trochamina dutsun, Anomalinoides midwayaensis and Ammobaculites anabiensis. That of the Mamu Formation constituting the basal part of the section at Ikpankwu quarry is dominated by Haplophragmoides Species including (H. Saheliense and H. Talokaensis), Ammobaculites texanus. These species assemblages define the age range of Maastrichtian, especially, between Campanian-Maastrichtian and Late Maastrichtian-Paleocene for Mamu Formation and Nsukka Formation sediments, respectively [20] [44]. The formation Fossil, Ammoastuta assemblages, consisting of Ammoastuta, Ammobaculites, Haplophragmoides, Trochammina and others have been described from the Coniacian to Turonian foraminifera from Ashaka northeastern Nigeria [40], where they were interpreted to be of brackish lagoonal to marsh origin.

Paleoenvironmental interpretations were also carried out based on the abundance and diversity of the micro fauna encountered and the presence of environmentally significant fauna. These sediments were interpreted to be deposited within a Non-marine (Coastal Deltaic) to middle neritic paleo-water depths. These paleobathymetric depth ranges when compared with the bathymetric ranges used in paleoenvironmental interpretations indicated that the sediments were deposited in marginal marine to shallow marine environments [21].

\subsection{Interpretations Using Palynomorphs}

Palynomorphs study of samples in the study area showed that samples from Nsukka Formation at Km 75 Enugu-Port Harcourt road, Ihube and the upper parts of the section at Ikpankwu are characterized by forms such as Leiotriletes adrennis, Retitricolporites annulatus, ongapertites sp., Trifossa pollenites sp., Apectodinium sp., Ephedripites sp., Noothofaqidites sp., Hexaporotricolpites. Some organic walled micro planktons such as Dinogymnoids indet were also found. The shale at the basal parts of the Ikpankwu quarry section, is characterized on the other hand by forms such as Retitrcolporites annulatus, Spinizoncol- 
pites echinatus, Lycopodiumsporites sp, Emelianova, and Foram lining. These assemblages at the basal and upper sections suggest Campanian-Maastrichtian and late Maastrichtian-Paleocene age indicative of Mamu and Nsukka Formation sediments respectively [45] [46] [47].

\section{Conclusions}

This study integrated lithofacies and biofacies data to characterize the environment of deposition (EOD) and lithostratigraphy of Upper Cretaceous sediments exposed along the Ikpankwu-Ihube axis, Okigwe within the Anambra Basin, Southeastern Nigeria. Based on the lithofacies analysis, abundance and diversity of micro fauna, environmental settings ranging from non-marine (coastal-deltaic) to middle neritic paleo-water depths typical of marginal to shallow marine environments of deposition have been inferred for the sediments.

Recovered foraminiferal and palynological assemblages were also used to define and appropriately place the boundaries between Nsukka and Mamu Formation sediments in the study area. The upper and basal parts of the sections are dominated by the Nsukka and Mamu Formation sediments, respectively.

The study has thus resolved the controversy on the geology of Ihube area for better mapping and correlation.

\section{Conflicts of Interest}

The authors declare no conflicts of interest regarding the publication of this paper.

\section{References}

[1] Nwajide, C.S. (2005) Anambra Basin of Nigeria: Synoptic Basin Analysis as a Basis for Evaluation Its Hydrocarbon Prospectivity. In: Okogbue, C.O., Ed., Hydrocarbon Potentials of the Anambra Basin: Geology, Geochemistry and Geohistory Perspectives, Great AP Express Publishers Ltd. for Petroleum Technology Development Fund Chair, Nsukka, 2-46.

[2] Onyekuru, S.O., Iwuagwu, C.J., Nwankwor, G.I., Onu, N.N. and Ukaonu, C.E. (2013) Dispersal Patterns of the Late Cretaceous to Early-Tertiary Sediments in the Southern Anambra Basin, Southeastern Nigeria. International Journal of Geosciences, 4, 588-604. https://doi.org/10.4236/ijg.2013.43054

[3] Reyment, R.A. (1965) Aspects of the Geology of Nigeria: The Stratigraphy of the Cretaceous and Cenozoic Deposits. Ibadan University Press, Ibadan, 145.

[4] Wright, J.B. (1981) Review of the Origin and Evolution of Benue Trough in Nigeria. Earth Evolution of Benue Trough, 1, 98-103.

[5] Obasi, A.I., Selemo, A.O.I. and Nomeh, J.S. (2017) Gravity Models as Tool for Basin Boundary Demarcation: A Case Study of Anambra Basin, Southeastern Nigeria. Journal of Applied Geophysics, 156, 31-43. https://doi.org/10.1016/j.jappgeo.2017.11.002

[6] Ola-Buraimo, A.O. and Akaegbobi, I.M. (2013) Palynological Evidence of the Oldest (Albian) Sediment in the Anambra Basin, Southeastern Nigeria. Journal of Biological and Chemical Research, 30, 387-408. 
[7] Onyekuru, S.O. (2009) Depositional Patterns of Late Cretaceous and Tertiary Sediments in Southern Anambra Basin and Niger Delta. Unpublished PhD Thesis, Federal University of Technology, Owerri, $303 \mathrm{p}$.

[8] Onyekuru, S.O., Opara, K.D. and Iwuagwu, C.J. (2018) Finite Markov Chain Model in Lithofacies Analysis: An Example from the Campanian-Maastrichtian Successions in the Okigwe-Uturu Axis Anambra Basin, SE Nigeria. FUTO Journal Series, 4, 393-408.

[9] Iwuagwu, C.J. (1993) Sedimentary Facies Analysis of Bima Sandstone Formation Gombe Area, Northeastern Nigeria. Giornale di Geologia, Ser. 3A, 55, 159-170.

[10] Okoro, A.U. and Ezeh, H.N. (2010) Finite Markov Chain Model in Lithofacies Analysis: An Example from the Bida Sandstone, Bida Basin, Nigeria. Global Journal of Geological Sciences, 8, 17-23. https://doi.org/10.4314/gjgs.v8i1.53793

[11] Oboh-Ikuenobe, F.E., Obi, C.G. and Carlos, A.J. (2005) Lithofacies, Palynofacies, and Sequence Stratigraphy of Paleogene Strata in Southeastern Nigeria. Journal of African Earth Science, 41, 79-101. https://doi.org/10.1016/j.jafrearsci.2005.02.002

[12] Murat, R.C. (1972) Stratigraphy and Paleogeography of the Cretaceous and Lower Tertiary I Southern Nigeria. In: African Geology, University of Ibadan Press, Ibadan, 251-266.

[13] Burke, K.C. (1996) The African Plate. South African Journal of Geology, 99, 341-409.

[14] Short, K.C. and Stauble, A.J. (1967) Outline of Geology of Niger Delta. American Association of Petroleum Geologist Bulletin, 51, 761-779. https://doi.org/10.1306/5D25C0CF-16C1-11D7-8645000102C1865D

[15] Obi, G.C., Okogbue, C.O. and Nwajide, C.S. (2001) Evolution of the Enugu Cuesta: A Tectonically Driven Erosional Process. Global Journal of Pure and Applied Sciences, 7, 321-330. https://doi.org/10.4314/gjpas.v7i2.16251

[16] Nigeria Geological Survey Agency (2005) Geological Sheet Map of Okigwe. No. 89, Sheet 312 .

[17] Selly, R.C. (1970) Ancient Sedimentary Environments. Chapman and Hall, Ltd., London, $237 \mathrm{p}$.

[18] Walker, R.G. and Cant, D.J. (1979) Model 3: Sandy Fluvial Systems. In: Walker, R.G., Ed., Facies Models Geoscience, Geological Association of Canada, St. John's, 23-31.

[19] Miall, A.D. (1973) Markov Chain Analysis Applied to Ancient Alluvial Plain Successions. Sedimentology, 20, 347-364. https://doi.org/10.1111/j.1365-3091.1973.tb01615.x

[20] Gebhardt, H. (1998) Benthic Foraminiferal from the Maastrichtian Lower Mamu Formation near Leru (Southern Nigeria): Paleoecology and Paleogeographic Significance. Journal of Foraminiferal Research, 28, 78-89.

[21] Uzoegbu, M.U. (2018) Palyno-Petrological Investigation of Upper Maastrichtian Strata, Afikpo Basin, SE Nigeria. International Journal of Research Publication, 3, 16. http://ijrp.org/paper_detail/71

[22] Peters, S.W. (1980) Biostratigraphy of Upper Cretaceous Forminifera of the Benue Trough, Nigeria. Journal of Foraminiferal Research, 10, 191-204. https://doi.org/10.2113/gsjfr.10.3.191

[23] Davey, R.J., Downie, C., Sargeant, W.A.S. and Williams, G.L. (1966) Studies on Mesozoic and Cainozoic Dinoflagellate Cysts: British Mus. (Natural History) Geology Supplement, 3, 248.

[24] Einsenack, A. (1958) Tasmanites Newton 1875 und leiosphaeridia n.g. als Gattun- 
gen der Hystrichosphaeridea. Palaeontographica, Abteilung A, 110, 1-9.

[25] Van der Hammen, T. (1954) El desarrollo de la flora Columbiaus en los perindos geologieos. Maestrictian Basin Terciarin mas inferior. Bol. Geol. Begata, 2, 49-106.

[26] Van Hoeken-Klinkenberg, P.M.J. (1964) Palynological Investigation of Some Upper Cretaceous Sediments in Nigeria. Pollen Spores, 6, 209-231.

[27] Miall, A.D. (2000) Principles of Sedimentary Basin Analysis. 3rd Edition, SpringerVerlag, Berlin, Heidelberg, 616. https://doi.org/10.1007/978-3-662-03999-1

[28] Reading, H.G. (1996) Sedimentary Environments and Facies. Blackwell Scientific Publications, Hoboken.

[29] Tucker, M.E. (2003) Sedimentary Rocks in the Field. 3rd Edition, John Wiley and Sons Limited, Hoboken, 234 p.

[30] Onuigbo, E.N., Okoro, A.U., Obiadi, I.I., Akpunonu, E.O., Okeke, H.C. and Maduewesi, V.U. (2012) Tide-Generated Sedimentary Structures, Lithofacies and Particle Size Distribution: Proxies to the Depositional Setting of the Ajali Sandstone in the Anambra Basin, Southeastern Nigeria. Journal of Natural Science Research, 2, 100 112.

[31] Ezenwaka, K.C., Odoh, B.I. and Ede, T.A. (2015) Lithofacies Analysis and Depositional Environments of the Eocene Nanka Sand as Exposed at Alor and Environs, Southeastern Nigeria: Evidence from Field Study and Granulometric Analysis. Journal of Natural Sciences Research, 5, 44-54. http://www.iiste.org

[32] Boggs, S. (2006) Principles of Sedimentology and Stratigraphy. Pearson Education, Inc., Upper Saddle River, 145-147.

[33] MacEachern, J.A., Raychaudhuri, I. and Pemberton, S.G. (1992) Stratigraphic Applications of the Glossifungites Ichnofacies: Delineating Discontinuities in the Rock Record. In: Pemberton, S.G., Ed., Applications of Ichnology to Petroleum Exploration, SEPM Core Workshop No. 17, 169-198. https://doi.org/10.2110/cor.92.01.0169

[34] Pemberton, S.G., MacEachern, J.A. and Frey, R.W. (1992) Trace Fossil Facies Models: Environmental and Allostratigraphic Significance. In: Walker, R.G. and James, N.P., Eds., Facies Models. Response to Sea Level Change, Geological Association of Canada, St. John's, 47-72.

[35] Mode, A.W. and Odumodu, C.F.R. (2014) Lithofacies and Ichnology of the Late Maastrichtian-Danian Nsukka Formation in the Okigwe Area, Anambra Basin, Southeastern Nigeria. Arabian Journal of Geosciences, 8, 7455-7466. https://doi.org/10.1007/s12517-014-1742-y

[36] Odumodu, C.F.R. and Okon, O.S. (2016) The Paleoenvironmental Significance of Trace Fossils from the Paleocene Imo Formation, South-Eastern Nigeria. Journal of Natural Sciences Research, 6, 101-109. http://www.iiste.org

[37] Okoro, A.U. and Igwe, E.O. (2014) Lithofacies and Depositional Environment of the Amaesiri Sandstone, Southern Benue Trough, Nigeria. Journal of African Earth Sciences, 100, 179-190. https://doi.org/10.1016/j.jafrearsci.2014.05.009

[38] Blatt, H., Tracy, R.J. and Owens, B.E. (2006) Petrology, Igneous, Sedimentary, and Metamorphic. 3rd Edition, W.H. Freeman \& Company, New York.

[39] Prothero, D.R. and Schwab, F. (1996) Sedimentary Geology. W.H. Freeman and Company, New York, 575.

[40] Rubin, D.M. and Carter, C.L. (2006) Bed Forms and Cross-Bedding in Animation. Society for Sedimentary Geology (SEPM), Atlas, Series 2.

[41] Stow, A.V. (2009) Sedimentary Rocks in the Field. A Colour Guide. 3rd Edition.

[42] Akande, S.O. and Mucke, A. (1993) Depositional Environment and Diagenesis of 
Carbonates at Mamu/Nkporo Shale within the Anambra Basin, Nigeria. Journal of African Earth Sciences, 17, 445-456. https://doi.org/10.1016/0899-5362(93)90003-9

[43] Obi, G.C. (2000) Depositional Model for the Campano-Maastrichtian Anambra Basin, Southern Nigeria. Unpublished PhD Thesis, University of Nigeria, Nsukka, 291 p.

[44] Murray, J.W. (1991) Ecology and Paleoecology of Benthonic Foraminifera. Longman Scientific \& Technical, London, 397.

[45] Gebhardt, H. (1997) Cenomanian to Turonian Foraminifera from Ashaka (NE Nigeria): Quantitative Analysis and Paleoenvironmental Interpretation. Cretaceous Research, 18, 17-36. https://doi.org/10.1006/cres.1996.0047

[46] Igwe, E.O. (2015) Aspects of Sedimentology, Stratigraphy and Paleogeography of the Eze-Aku Group (Late Cenomanian to Turonian) in the Afikpo Synclinorium, Southern Benue Trough, Nigeria. Unpublished PhD Thesis, Department of Geology, Ebonyi State University, Abakaliki, 194 p. https://doi.org/10.1016/j.jafrearsci.2016.03.016

[47] Mode, A.W. (1991) Assemblage Zones, Age, and Paleoenvironment of the Nkporo Shale, Akanu Area, Ohafia Southeastern Nigeria. Journal of Mining and Geology, 27, 104-114. 